REFLECTIONS:

NEUROLOGY AND

THE HUMANITIES

Section Editor

Anne W. McCammon,

MD, FAAN

\section{Like it or not}

"Skipper, the docs in casualty receiving sent me to get you."

In the US Navy, addressing your commanding officer as Skipper was not only appropriate, most commanding officers desired it.

"They said you would want to see this one," the corpsman continued.

I rather doubted that. I had already seen more than I ever wanted to see. And from the tone in the corpsman's voice, I knew this was going to be gruesome. Nonetheless, I had instructed my department heads to have me immediately informed if anything happened that I should know about. I never wanted to be blindsided. No commanding officer should ever say, "I was not aware of that." I was responsible and accountable for every action that occurred in the combat support hospital and 10 troop medical clinics that I commanded in Kuwait and Qatar.

On our way to casualty receiving, the corpsman took me to the helicopter parked on our primary LZ (landing zone), located only 50 yards from the doors to casualty receiving. The helicopter was not one of the US Army Blackhawks that brought us the bulk of our serious business. This helicopter was from one of our Coalition allies. As I looked into the helicopter, I immediately saw its floor was covered in blood. Not a good sign.

"They did not exactly have good hemorrhage control, did they?" I remarked.

"That's not the worst of it, Sir. The wounded soldier was intubated, but no one was breathing for him. He had no IVs running, and CPR was not being done."

How could it be that anyone would medivac a wounded soldier and not follow the basic principles of life support? In disbelief, I asked, "What was the medic doing?"

"It wasn't the medic. It was the doctor, and she was crying hysterically."

My curiosity was piqued.

In casualty receiving, the image was, as I expected, gruesome. The soldier's body was lying on a gurney. There was a small clean linear entrance wound on his left lower cheek. The top of his skull was missing. Dura, brain, and bone were dangling from the edges of the ghastly crater that was the exit wound.
The surgeon and my director of clinical services pointed out to me the badly damaged brainstem which was readily visible in the depths of the wound.

"What do you think, Skipper?"

"I think this soldier was dead the instant he was shot."

The surgeon, smiling, responded, "Skipper, for a neurologist, your clinical skills are admirable."

Surgeons. You have to love their bravado and egos. However, I certainly was not going to do anything to squelch his spirit. I needed and depended upon that spirit in this place. Our surgeons were wonderful. They had saved many lives. Moreover, bravado and humor were the easiest psychological mechanisms to utilize in order to deal with carnage and horror so that one could remain mentally ready to calmly and effectively handle the next medical crisis.

"Where is the doctor who came in with this soldier?" I asked.

"She's out back. The chaplain and one of the psychiatrists are talking to her. You know, comforting and consoling her."

"What's the story with her?" I questioned.

"She's very junior, and she just got overwhelmed."

I understood and appreciated her situation immediately. She was a battalion medical officer in her nation's army. She had very limited medical assets and capabilities. She was functioning as the lone physician for her unit. This young reservist physician had just finished her residency and was being introduced to the military by serving a 90-day stint with her country's combat troops in Iraq-a rude introduction to the military and to war. She was just not yet psychologically prepared for this.

All of us now standing over this dead soldier's body had been battalion medical officers. In fact, this dead soldier's nation had operated the combat field hospital that had been my higher echelon medical support in the Balkans. The sense of feeling inadequate and functionally limited was natural in battalion medical officers. In that role, I had prayed and hoped that no medical situation would arise that would overwhelm me.

Listen to Dr. Riggs read this story, available exclusively on Neurology ${ }^{\circledR}$ for the iPad ${ }^{\circledR}$

Any assertions and opinions, explicit or implicit, are those of the author and should not be construed to represent those of the United States Navy or any other military organization involved in Operation Iraqi Freedom. 
Despite the tragedy lying in front of us on that gurney, I saw my opportunity to take a shot back at my two surgical colleagues for their neurologist remark. I eagerly took it.

"You bastards," I said, smiling, "you did not send for me to come and see another dead soldier. You guys grabbed the good cop role, and now you expect me to be the bad cop."

"She has to learn. And besides, that's what they pay you the big bucks for," said the surgeon.

They were right. This young physician ally and colleague needed to be told what she had done wrong, and I was the appropriate person to tell her in this situation since she was not a US military physician.

I walked out back behind the hospital. The chaplain, one of our psychiatrists, and this young army captain were sitting on the base of one of the concrete barriers that surrounded our tent hospital complex. As I approached, I motioned for the chaplain and the psychiatrist to leave us alone. Praise in public, criticize in private. I was not about to violate that leadership dictum. Although English was not her native language, fortunately for me, she spoke and understood English well.

"I'm Captain Riggs, commanding officer of US Military Hospital Kuwait. I want you to understand how very sorry we are about the loss of your soldier. There was nothing you did or did not do that had any impact on his survival from that gunshot wound. There is also nothing wrong with crying. This is an insane place filled with unspeakable horror and tragedy. You would not be human if you did not cry. But you screwed up on two counts."

She was young and scared. Her lower lip quivered, and her eyes began to water again. I felt terrible for her, but there was no turning back. Nor would there be any comforting of her on my part. To be quickly ingrained and entrenched into her psyche, this lesson had to be blunt, and it had to hurt. I suspected she already knew what I was going to say because she would have observed the actions of the surgeons when her soldier was rushed into casualty receiving. After one quick look, she would have seen them do nothing.
"Your soldier was obviously dead the instant he was shot. Your first mistake was that you allowed a medivac mission to take place in a combat zone that served no military purpose. You placed the flight crew of that helicopter and yourself at risk for no reason. Death already seems so senseless and needless here. You are a military physician. You cannot contribute to the risk of more senseless and needless death. Your second mistake was that you became paralyzed in front of your troops. Your troops see you as their first line of defense if they get injured. If they see you paralyzed into inaction in a medically intense situation, you will undermine their morale. They have to believe that you will be there for them if they need you. I want you to go back into casualty receiving and examine your soldier with our surgeons. You must learn from this episode. You are here. You can do it. You must do it. Like it or not, you must think and act like a military physician."

I walked with her back to casualty receiving and left her with the surgeons. As I continued on alone to my office, I could not help but think about that dead soldier's family. They were at home, somewhere, still going about their daily activities. But deep in their minds, they were always worried about the safety of their loved one. They did not yet know that their worst nightmare had already been realized. Those same disturbing thoughts had already played out in my mind on far too many occasions.

As I got back to my desk, I thought how much I hated this place. Those thoughts were pervasive among my shipmates and the soldiers who shared this sandbox. What would be difficult to understand, however, was that despite a strong desire to get home, once we got home, home just did not feel quite right. For some reason, you felt as if you needed to be back here. That uncomfortable feeling would eventually become easier for me to deal with once I accepted and understood that a part of me would always be here, and that I could never fully come home.

As I sat down at my desk and my eyes began to water, I told myself, "You are here. You can do it. You must do it. Like it or not, you must think and act like a military physician.” 


\title{
Neurology
}

\author{
Like it or not \\ Jack E. Riggs \\ Neurology 2014;82;e136-e137 \\ DOI 10.1212/WNL.0000000000000347
}

This information is current as of April 21, 2014

\section{Updated Information \&} Services

\section{Subspecialty Collections}

Permissions \& Licensing

Reprints including high resolution figures, can be found at: http://n.neurology.org/content/82/16/e136.full

This article, along with others on similar topics, appears in the following collection(s):

\section{All Ethics in Neurology/Legal issues}

http://n.neurology.org/cgi/collection/all_ethics_in_neurology_legal_iss ues

Information about reproducing this article in parts (figures,tables) or in its entirety can be found online at:

http://www.neurology.org/about/about_the_journal\#permissions

Information about ordering reprints can be found online: http://n.neurology.org/subscribers/advertise

Neurology ${ }^{\circledR}$ is the official journal of the American Academy of Neurology. Published continuously since 1951, it is now a weekly with 48 issues per year. Copyright (O) 2014 American Academy of Neurology. All rights reserved. Print ISSN: 0028-3878. Online ISSN: 1526-632X.

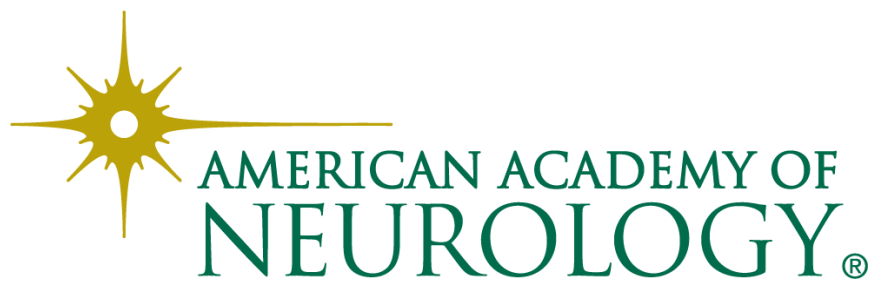

